\title{
CHRONIC RENAL FAILURE; \\ STUDY OF THYROID HORMONE LEVELS IN UN-DIALYZED PATIENTS
}

1. FCPS

Assistant Professor Physiology at Jinnah Sindh Medical University Karachi.

2. FCPS

Assistant Professor Medicine LUMHS.

3. MBBS, FCPS

Senior Registrar Nephrology Liaquat University of Medical \& Health Sciences, Jamshoro.

\section{Correspondence Address:}

Dr. Santosh Kumar

Assistant Professor

LUMHS.

03332971987

dr_santosh72@yahoo.com

Article received on: 20/02/2017

Accepted for publication: $15 / 08 / 2017$

Received after proof reading:

06/10/2017
Noor Un Nisa Memon', Santosh Kumar², Bhagwan Das ${ }^{3}$

ABSTRACT: Objectives: To compare thyroid hormone levels in apparently healthy individuals and un-dialyzed chronic renal failure patients in local population. Study Design: Crosssectional, descriptive, observational study. Setting: OPD patients in BMSI Biomedical Science Institute of Medical Jinnah Medical Karachi. Period: June 2010 to December 2010 in BMSI JPMC, Karachi. Methods: Ninety individuals including 30 healthy control and 60 patients of chronic renal failure were included in this study. Individuals were grouped based on severity of diseases (stages) as healthy (control) group and the diseased group. Patients with un-dialyzed CRF on conservative management, GFR $<60 \mathrm{ml} / \mathrm{mint} / 1.73 \mathrm{~m}^{2}$, age between 20 to 60 years in both sexes were included in this study. Patients already taking thyroxine or antithyroid drugs, history of thyroid surgery and neck radiation and patients on maintenance haemodialysis were excluded. Measurement of thyroid hormone levels were done through Radio Imune Assay (RIA) method and GFR by Cock Craft Gualt formula. Results: Serum $\mathrm{FT}_{3}$ significantly low in patients with CRF of stage III $1.27 \pm 0.12$, stage IV $1.04 \pm 0.09$ vs $2.80 \pm 0.09$ in controls, $p=0.001$. TSH was significantly high in patients of CRF as compared to control $4.41 \pm 0.87$ and $3.3 \pm 0.34$ vs $1.97 \pm 0.16, P=0.001$. No significant difference was seen in serum $\mathrm{FT}_{4}$ levels Conclusion: In local population thyroid hormone level of FT3 declines with the severity of Glomerular Filtration Rate as compare to healthy individuals. However, TSH level increases with this severity as also reported in other countries. Additionally, FT3 level is helpful for early detection and prevention of complications. Local population need awareness to prevent CRF by reporting to hospital before stage 3 .

Key words: $\quad$ Thyroid hormone, healthy individuals, $\mathrm{TSH}$, chronic renal failure.

Article Citation: Memon N, Kumar S, Das B. Chronic renal failure; study of thyroid hormone levels in un-dialyzed patients. Professional Med J 2017;24(10):000-000. DOI:10.17957/TPMJ/17.3793

\section{INTRODUCTION}

Thyroid gland is one of the largest endocrine gland in the body. Thyroid secretes two hormones, thyroxine $\left(\mathrm{T}_{4}\right)$ and tri-iodothyronine $\left(\mathrm{T}_{3}\right)$. It also secretes calcitonin, an important hormone for calcium metabolism. ${ }^{1}$

Thyroid gland is composed of many spherical structure called follicles or acini as a functional unit. $^{2}$ The cells of the follicles produce this colloid which is largely composed of thyroglobulin. Between the follicles are the parafollicular or $\mathrm{C}$ (clear) cells. ${ }^{3}$

About $93 \%$ hormone produced by this gland is thyroxine and $7 \%$ is tri-iodothyronine. However, almost all the thyroxine is converted eventually to tri-iodothyronine in tissues.
The most common endocrinopathy and most preventable cause of mental retardation is deficiency of iodine or metabolic problem. ${ }^{4}$ Inadequate iodine supply leads first to inadequate thyroid hormone productions and then to inadequate tissue response i.e. hypothyroidism. ${ }^{5}$

The prevalence of hyperthyroidism/ hypothyroidism varies in different countries while in our country Pakistan ratio of hyperthyroidism in chronic renal failure is about 5.1-5.8 \% while hypothyroidism about 4 to $4.5 \%$ much higher in female than male patients. ${ }^{6}$

Chronic renal failure is a state of irreversible deceleration in renal functions. It has been also observed that if $<10 \%$ of renal functions remain, it is termed as end stage renal disease (ESRD). 
This permanent loss of renal functions culminates in sign and symptoms termed as uremia. ${ }^{7}$

CRF is also defined as either kidney damage or decreased renal functions (decreased GFR) for three months or more than three months. ${ }^{8,9}$

Disturbances in endocrine functions are commonly seen in patients with chronic renal failure. Change in the secretion and metabolism of hormones as well as alteration in target organs sensitivity account for these alterations. ${ }^{10,11}$

The kidney normally contributes towards clearance of iodide from the body. In chronic renal failure iodide excretion is diminished leading sequentially to an elevated plasma inorganic iodide concentration and initial increment in thyroidal iodide uptake. ${ }^{12,13}$

\section{PATIENTS AND METHODS}

This was a cross-sectional, descriptive, observational study that required no therapeutic interventions was performed OPD patients in BMSI biomedical science institute of medical Jinnah Medical Karachi. This study conducted between June 2010 to December 2010 in BMSI jpmc Karachi, 90 pts included in this study with undialsed stage. There were 30 normal healthy control and 60 patients with CRF were recruited from out patients department (OPD) of Nephrology, JPMC. CRF was defined as an estimated GFR $<60 \mathrm{ml} / \mathrm{min} / 1.73 \mathrm{~m}^{2}$ for more than 3 months. The study based on 03 groups, in which patients were selected randomly. Age matched controls were selected among local population of same socioeconomic group through convenient sampling. Anthropometric and blood pressure measurement was done according to standard methods in all subjects.

\section{Calculations}

To segregates the patient according to the degree of renal dysfunction estimated GFR was calculated using Cock Craft Gualt formula.

The CRF Patients were grouped as Moderate (GFR $<60-30 \mathrm{ml} / \mathrm{min} / 1.73 \mathrm{~m}^{2}$ ) and Severe (GFR<30). According to chronic kidney disease classification by National Kidney Foundation.

All participants gave written informed consent and ethical committee of Jinnah Post Graduate Medical Centre Karachi.

All blood draws were performed at Nephrogy Laboratory, JPMC. Venous blood samples were taken and samples were centrifuged within 30 minutes of collection. Separated serum was immediately frozen at $-20 \mathrm{C}$.

\section{Inclusion Criteria}

- Undialyzed pt with chronic renal failure on conservative management.

- $\quad$ Age between 20 - 60 years.

- $\quad$ Both group sex male and female

All patients included were recorded on specially designed proforma (Appendix I) for information.

\section{Exclusion Criteria}

Following patients were excluded from the study:

- Patients already taking thyroxine or anti thyroid drugs.

- $\quad$ Patients with history of thyroid surgery.

- Patients who have history of neck radiation.

- Patients on maintenance haemodialysis.

\section{STATISTICAL ANALYSIS}

Analysis were done on SPSS version 13.0 was used for data feeding and analysis. The results were given in the text as mean and standard error of mean (SEM) for continuous/qualitative variables (age, pulse rate, respiratory rate, weight, blood pressure, $\mathrm{FT}_{3}, \mathrm{FT}_{4}$ and $\mathrm{TSH}$ etc.). p-value $<0.05$ suggest that my study favor my results and reject null hypothesis.

\section{RESULTS}

90 patients registered 60 were recruited from out patient department of nephrology and 30 were healthy individuals (both gender) of local population. The study was divided into 03 groups, control group A consisting of healthy individuals, group B (test group), Stage III and group C (test group) stage IV of chronic renal failure. 


\begin{tabular}{|l|c|c|c|}
\hline \multicolumn{1}{|c|}{ Parameters } & Control & Stage III & Stage IV \\
\hline & (Group A) & (Group B) & $53.30 \pm 1.52$ \\
\hline Age (Years) & $44.21 \pm 1.84$ & $50.33 \pm 1.50$ & $65.80^{\star} \pm 2.25$ \\
\hline Weight $(\mathrm{Kg})$ & $53.63 \pm 1.37$ & $68.37^{\star} \pm 1.82$ & $136.67^{\star} \pm 1.68$ \\
\hline Systolic blood pressure $(\mathrm{mmHg})$ & $109.33 \pm 1.26$ & $137.00^{\star} \pm 2.31$ & $91.00^{\star} \pm 1.62$ \\
\hline Diastolic blood pressure $(\mathrm{mmHg})$ & $69.67 \pm 1.22$ & $91.33^{\star} \pm 1.63$ & (G) \\
\hline
\end{tabular}

Table-l. Comparison of age (years) weight $(\mathrm{kg})$ and blood pressure among different groups

*Difference were statistically significant as compared to controls $p<0.01$

\begin{tabular}{|l|c|c|c|}
\hline \multicolumn{1}{|c|}{ Parameters } & $\begin{array}{c}\text { Control (Group A) } \\
(\mathbf{n = 3 0 )} \text { Mean } \pm \text { SEM }\end{array}$ & $\begin{array}{c}\text { Stage III (Group B) } \\
(\mathbf{n = 3 0}) \text { Mean } \pm \text { SEM }\end{array}$ & $\begin{array}{c}\text { Stage IV (Group C) } \\
(\mathbf{n = 3 0}) \text { Mean } \pm \text { SEM }\end{array}$ \\
\hline Serum $\mathrm{FT}_{3}(\mathrm{pg} / \mathrm{ml})$ & $2.80 \pm 0.09$ & $1.27 \pm 0.12$ & $1.04 \pm 0.09^{\star}$ \\
\hline Serum $\mathrm{FT}_{4}(\mathrm{ng} / \mathrm{dl})$ & $1.42 \pm 0.08$ & $1.49 \pm 0.58$ & $1.43 \pm 005$ \\
\hline Serum TSH $(\mu \mathrm{lU} / \mathrm{ml})$ & $1.97 \pm 0.16$ & $4.14^{\star} \pm 0.87$ & $3.33 \pm 0.34^{\star}$ \\
\hline & $\begin{array}{c}\text { Table-II. Comparison of } \mathrm{ft}_{3}, \mathrm{ft}_{4} \text { and TSH levels among different groups } \\
\text { *Difference were statistically significant as compared to control } \mathrm{p}<0.01 .\end{array}$ \\
\hline
\end{tabular}

\section{DISCUSSION}

Body weight was significantly higher in group B and $\mathrm{C}$ as compared to control group representing fluid and salt retention. Similar findings were reported by Fauci et al. (2008).

Systolic and diastolic blood pressures were high in chronic renal failure patients representing change in renin angiotensin system.

This is in agreement with the study conducted by Vargas et al. (2006) Additionally, Weiner et al. (2004) also observed that hypertension and diabetes mellitus are leading cause of chronic renal failure.

Our study showed that FT3 was low in patients with undialysed renal failure. Representing an impaired peripheral conversion of FT4. This is in agreement with Lim (2001) and Zoccali et al. (2005).

Thus low FT3 is a major feature of disturbances in chronic renal failure which is considered as a counter regulatory response and minimizing energy, protein wasting, uncontrolled diabetes mellitus with diabetic ketoacidosis.

Increased mortality is associated with low FT3 as reported by (Zoccali et al., 2006). Lo et al. ${ }^{1}$ found that thyroid disease and CRF increases public health problem. A number of alterations in thyroid hormone levels and metabolisms have been reported in patients with CRF and also low level of $T_{3}$ has been found to be most common disturbances. ${ }^{2,3}$

In the present study no significant difference was observed between level of $\mathrm{FT}_{4}$ and controls.

\section{CONCLUSION}

In local population thyroid hormone level of FT3 declines with the severity of Glomerular Filtration Rate as compare to healthy individuals.

However, TSH level increases with this severity as also reported in other countries.

Additionally, FT3 level is helpful for early detection and prevention of complications.

Local population need awareness to prevent CRF by reporting to hospital before stage

\section{ACKNOWLEDGEMENTS}

We great fully acknowledge the valuable suggestions given by Dr. Abdul Shakoor Memon, Dr. Abdul Manan Junejo and Mrs. Nudrat Anwar Zuberi in modifying research design and method. Mr. Akhtar Anwar for help in data analysis, Illahi Bux Shaikh in lab work and compiling by Nisar Muhammad Usmani.

Copyright(®) 15 Aug, 2017.

\section{REFERENCES}

1. Guyton AC, Hall JE. Thyroid metabolic hormones. In: Textbook of Medical Physiology $11^{\text {th }}$ edition, 2006; 
pp.931-942.

2. Roberts A. The thyroid gland 1. Nurs Times 1995; $91(37): 33-35$.

3. Shagam JY. Thyroid disease: an overview. Radiol Techno 2001; 73(1):25-40.

4. Dunn JT. Extensive personal experience: seven deadly sins in confronting endemic iodine deficiency, and how to avoid them. J Clin Endocrinol Metabol 1996; $81(4): 1332-1335$.

5. Dunn JT. Editorial: What's happening to our iodine. J Clin Endocrinol Metabol 1998; 83(10):3398-3400.

6. Khan A, Khan MMA and Akhtar S. Thyroid disorders, etiology and prevalence. J Med Sci 2002; 2(2):89-94.

7. Singh PA, Bobby Z, Selvaraj N, Vinayagamoorthi R. An evaluation of thyroid hormone status and oxidative stress in undialyzed chronic renal failure patients. Indian J Physiol Pharmacol 2006; 50(3):279-284.

8. Levey AS, Coresh J, Balk E, Kausz AT, Levin A and Steffes MW. National kidney foundation practice guidelines for chronic kidney disease: Evaluation, classification, and stratification. Ann Intern Med 2003; 139:137-147.

9. Weiner DE, Tighiouart $H$, Amin MG et al. Chronic kidney disease as a risk factor for cardiovascular disease and all-cause mortality: a pooled analysis of community based studies. J Am Soc nephrol 2004; 15:1307-1315.

10. National Kidney Foundation. K/DOQI clinical guidelines for chronic kidney disease: evaluation, classification, and stratification. Am J Kidney Dis 2002; 39(2):S46-s75.

11. Palmer BF. Metabolic disturbances in chronic renal failure. Saudi J Kid Dis Transp 2002; 13(3):273-280.

12. Avasthi G, Malhotra S, Narang APS, Sengupta S. Study of thyroid function in patients of chronic renal failure. Indian J Nephrol 2001; 11:165-169.

13. Lin CC, Chen TW, Ng YY, Chou YH and Yang WC. Thyroid dysfunction and nodular goiter in hemodialysis and peritoneal dialysis patients. Perit Dial Int 1998; 18:516521.

14. Hollander DJG, Wulkant RW, Mantelt MJ, Berghoot A. Correlation between severity of thyroid dysfunction and renal function. Clin Endocrinol 2005; 62:423-427.

15. Lo JC, Chertow GM, Go AS, Hsu CY. Increased prevalence of subclinical and clinical hypothyroidism in persons with chronic kidney disease. Kidney Intern 2005; 67:1047-1042.

16. Lervasi G, Pingitore A, Landi P, Raciti M, Ripoli A, Scarlattini M, L'Abbate A, Donato L. Low-T3 syndrome: A strong prognostic predictor of death in patients with heart disease. Circulation 2003; 107:708-713.

17. Chonchol M, Lippi G, Salvagno G, Zoppini G, Muggeo M, Targher G. Prevalence of subclinical hypothyroidism in patients with chronic kidney disease. Clin J Am Soc Nephrol 2008; 3:1296-1300.

18. Lim VS. Thyroid function in patients with chronic renal failure. Am J Kidney Dis 2001; 38(4):S80-S84.

19. Zoccali C, Tripepi G, Cutrupi S, Pizzini P and Mallamaci F. Low Triiodothyronine: A new fact of inflammation in end stage renal disease. J Am Soc Nephrol 2005; 16:2789-2795.

20. Witzke O, Wiemann J, Patschan D, Wu K, Philipp T, Saller $B$. Differential $T_{4}$ degradation pathways in young patients with preterminal and terminal renal failure. Hormone Metab Res 2007; 39:355-358.

21. Kutlay S, Atli T, Koseogullari O, Nergizoglu G, Duman $\mathrm{N}$ and Gullu S. Thyroid disorders in hemodialysis patients in an iodine deficient community. Artif Organs 2005; 29(4):329-332.

22. Carrero JJ, Qureshi AR, Axelsson J, Yilmaz MI, Rehnmark S. Clinical and biochemical implications of low thyroid hormone levels (total and free forms) in euthyroid patients with chronic kidney disease. $J$ Internal Medicine 2007; 262:690-671.

23. Lippi G, Montagnana M, Targher G, Salvagno GL, Guidi GC. Relationship between thyroid status and renal function in a general population of unselected outpatients. Clin Biochem 2008; 41:425-427.

\section{AUTHORSHIP AND CONTRIBUTION DECLARATION}

\begin{tabular}{|c|c|c|c|}
\hline Sr. \# & Author-s Full Name & Contribution to the paper & Author $=\mathbf{s}$ Signature \\
\hline 1 & $\begin{array}{l}\text { Noor Un Nisa Memon } \\
\text { Santosh Kumar }\end{array}$ & $\begin{array}{l}\text { Had helping, Idear, } \\
\text { Concept } \\
\text { Idea. Sampling }\end{array}$ & \\
\hline 3 & Bhagwan Das & Biostatisc, Reference & Wor \\
\hline
\end{tabular}

